\title{
Protection of Highbush Blueberry Plants against Phytophthora cinnamomi Using Serendipita indica
}

\author{
Aleksandra Trzewik* $*$, Agnieszka Marasek-Ciolakowska $\mathbb{D}$ and Teresa Orlikowska \\ Department of Applied Biology, Research Institute of Horticulture, Konstytucji 3 Maja 1/3 Str., \\ 96-100 Skierniewice, Poland; agnieszka.marasek@inhort.pl (A.M.-C.); Teresa.Orlikowska@inhort.pl (T.O.) \\ * Correspondence: Aleksandra.Trzewik@inhort.pl
}

Received: 28 August 2020; Accepted: 15 October 2020; Published: 18 October 2020

\begin{abstract}
A greenhouse experiment was carried out on the use of Serendipita indica, an endomycorrhizal-like fungus, to increase the resistance of three highbush blueberry cultivars Chandler, Darrow and Spartan to the pathogen Phytophthora cinnamomi. The cultivars differed in the acceptance of root colonisation by $S$. indica and in susceptibility to P. cinnamomi. The lowest percentage (\%) of colonised roots was found in the cultivar Spartan. The frequency of symptomatic plants (stunted growth, dark spots on stems, small, yellowing, and dropping leaves) among plants inoculated only with P. cinnamomi was 59, 83, and 100\%, for 'Chandler', 'Darrow', and 'Spartan', respectively. In the treatment where both pathogen and endophyte were inoculated, the frequency in 'Darrow' and 'Spartan' dropped to 28 and 90\%, respectively. Of non-protected 'Spartan' plants, $66 \%$ died, whereas only $14 \%$ of those protected with S. indica died. Colonisation by S. indica reduced the number of dead plants of 'Chandler' from 3 to 1 among those protected. In 'Darrow' only one plant died of the non-protected and none of the protected ones. S. indica increased the growth of non-infected plants of 'Darrow' and 'Spartan' by 11\%. An increase in the growth of plants inoculated with S. indica and infected with P. cinnamomi after 21 days went from $74 \%$ to $182 \%$ over the plants only infected with the pathogen.
\end{abstract}

Keywords: bio-protection; Serendipita indica; pathogen; highbush blueberry cultivars; resistance

\section{Introduction}

Highbush blueberry (Vaccinium corymbosum) fruit is valued for its health-promoting potential. It is a rich source of anthocyanins, mineral salts, and vitamins [1,2]. The fruits of highbush blueberry contain on average about $200 \mathrm{mg} / 100 \mathrm{~g}$ Fresh Weight of anthocyanins [2,3]. Several cultivars are bred for various soil and climate requirements, enabling their cultivation in several climatic conditions in numerous countries [4]. About $76 \%$ of the world's highbush blueberry fruit is produced in the United States, Chile, and Canada in 2016 [5]. World production amounted to 861.55 metric tons in 2016, and the increase in production was 16.3\% compared to 2014 [5]. Highbush blueberry is in the spotlight among European, South American, and Asian growers. This fruit is mostly consumed as fresh fruit, but processed products (frozen, jelly, saft) are also available on the market. The cultivation of highbush blueberry is the fastest growing direction of fruit production in Poland [6] where the interest in cultivation of highbush blueberry is growing due to its economic attractiveness and the fruits are sold at home and exported, mostly to the European Union. Poland produces approximately 21 thousand tons of these fruits, which ranks it a second in European (Statistics Poland 2017) and the seventh in global production of highbush blueberries [5].

Plants of the Ericaceae family are known for their high sensitivity to pathogens of the genus Phytophthora, including P. ramorum [7] and P. cinnamomi [8]. The method of plant production, on an industrial scale in nurseries and cropping fields, the need for frequent irrigation, and transfer of 
plant materials between climatic zones increases the possibility of epidemic occurrence of diseases. Highbush blueberry plants suffer from Phytophthora root rot, caused mostly by P. cinnamomi $[9,10]$ but also by P. citrophthora [11]. Orlikowski [12] published the first report on the recognition of P. cinnamomi on highbush blueberry in Polish plantations.

Admittedly, effective preparations are recommended for the prevention and protection of blueberry plants against Phytophthora spp., but they cannot be used in organic production, which is increasingly expected. There are some cultural practices that are recommended, enabling a reduction in the use of pesticides, namely, choice of proper field, soil mulching, irrigation method, and optimal content of $\mathrm{Ca}^{2+}$ in soil, among others $[13,14]$ but the most valuable is the planting of highly resistant plants. The endophytic fungus Serendipita indica (formerly Piriformospora indica) that colonises roots can stimulate plants to increase resistance against biotic and abiotic stress [15-18] and therefore, it can be applied as a factor that makes organic production easier [19]. The mechanism that determines plant resistance to pathogens has not been fully elucidated except that it is systemic in nature [15-18]. Studies on transcription profiles of tomato plants colonised with S. indica and infected with Alternaria solani have indicated the modulation of key enzymatic components related to the signaling system and defense-related genes activated after pathogen attack [20].

Our previous work on reducing rhododendron Phytophthora root rot using S. indica showed $50 \%$ effectivity in protection against P. cinnamomi and P. plurivora [21]. One-year-old rhododendron plants infected with P. cinnamomi or P. plurivora died out within 6 weeks, while plants inoculated with S. indica 3 weeks before Phytophthora infection survived (50-60\%) without any chemical treatment. The tendency to limit the chemisation of horticulture products and to have a safe production environment makes $S$. indica one of the endophytes, which can build the resistance of the plants thus limiting fungicide treatments.

The goal of this study was to recognise whether $S$. indica can help in the protection of highbush blueberry against P. cinnamomi.

\section{Materials and Methods}

\subsection{Plant Material}

Three cultivars of highbush blueberry (V. corymbosum), Chandler, Darrow, and Spartan, were used in the experiment. Plants were obtained by softwood micro-cuttings. At the beginning of the experiment in September 2017, plants were 6 months old with 2-3 shoots and a height of $10-15 \mathrm{~cm}$. There were 29 plants in each treatment. The experiment was carried out in a greenhouse at the Institute of Horticulture in Skierniewice for two years. The greenhouse was heated in spring and autumn so that the temperature was not lower than $15{ }^{\circ} \mathrm{C}$ or higher than $30^{\circ} \mathrm{C}$, and in spring and autumn it was lit up to 12 hours a day. During the winter, the plants were incubated in a greenhouse where temperature was from $4{ }^{\circ} \mathrm{C}$ to $7^{\circ} \mathrm{C}$.

\subsection{Preparation of S. indica Inoculum and Peat Substrate Inoculation}

Cultures of $S$. indica were stored at $25^{\circ} \mathrm{C}$ in the dark on $90 \mathrm{~mm}$ diameter Petri dishes containing Keafer medium (KM) [22]. The fungus was activated to colonise plant roots by co-cultivation every 6 months with roots of Arabidopsis thaliana (Columbia-0 ecotype) on Petri dishes, according to the recommendations of Johnson [23]. The mycelium of S. indica used in the experiment was produced in the liquid KM medium, as described by Trzewik [21]. The peat substrate was inoculated with $S$. indica with a proportion of $2 \mathrm{~g}$ mycelium and $100 \mathrm{~mL}$ peat $(2 \% w / v)$.

\subsection{Preparation of the Substrate Infected with P. cinnamomi}

P. cinnamomi used in our study was isolated from the rhizosphere of highbush blueberry plants with symptoms indicative for Phytophthora root rot [12]. The isolate was identified using morphological [24] and molecular markers based on the Internal Transcribed Spacer region [25]. To produce an infected 
substrate, $P$. cinnamomi was incubated in the dark for 7 days on an oatmeal substrate $(5 \mathrm{~g}$ oatmeal and $15 \mathrm{~mL}$ distilled water per $9 \mathrm{~cm}$ diameter Petri plate, autoclaved twice for $30 \mathrm{~min}$ with an interval of 24 hours), homogenised, and added to the peat in a proportion of one Petri dish per 1 litre of peat. Then, after $2-3$ weeks at $23{ }^{\circ} \mathrm{C}, 0.2 \mathrm{~kg}$ of the infected substrate was collected and the presence of P. cinnamomi zoospores was determined according to the procedure described by Themann [26], using rhododendron leaves as baits. Briefly, infected substrate was flooded with distilled water and leaves of rhododendron 'Nova Zembla' were placed on the surface of the water and incubated at $23^{\circ} \mathrm{C}$ in the dark for 4-5 days. After this time, leaves were taken out, washed under tap next distilled water and dabbed dry. On each leaf blade number of necrotic spots were counted. In sterile laminar bench chosen leaves were sterilised over a burner flame and small fragments of tissue were cut from individual necrotic spots and placed on PDA medium (Potato Dextrose Agar, Merck KGaA, Darmstadt, Germany) in 90-mm Petri dishes for fungus identification, which were made as described below (see Section 2.6). After 7 days, 1 litre of infected substrate was mixed with 10 litres of pure peat substrate.

\subsection{Inoculation of Highbush Blueberry Plants with S. indica and P. cinnamomi}

For the experiment, blueberries were planted into $500 \mathrm{~mL}$ plastic pots with a peat substrate dedicated to Ericaceae, $\mathrm{pH}$ 3.5-4.0 (Alonet, Skierniewice, Poland). There were four combinations, with 29 plants each, as follows: 1 - pure peat substrate, 2 -substrate inoculated with $S$. indica, 3 -substrate inoculated with P. cinnamomi, $4-250 \mathrm{~mL}$ of substrate inoculated with $S$. indica and after 21 days, supplementation with $250 \mathrm{~mL}$ of the substrate infected with P. cinnamomi. After planting, the substrate was carefully watered. The pots of single combination were placed in separate plastic boxes with a solid bottom lined with an underlying mat. During the winter, plants were maintained in a non-heated greenhouse. They were fertilised twice per year in April and May with Hydrovit (Hydrokomplet, Nowa Wieś, Poland) at a concentration of $1.25 \%$. The experiment was terminated in October 2019. Observations of the symptoms of the disease, such as wilting leaves, leaf discoloration and fineness, and stem tip and shoot necrosis, were initially made on a weekly basis, then every month for 24 months.

\subsection{Assessment of Colonisation of Highbush Blueberry Roots by S. indica}

The evaluation of root colonisation was carried out for combinations 2 and 4, after 9 months (5 plants were randomly chosen) and at the end of the experiment (10 plants). From each plant, $1.5 \mathrm{~cm}$ root fragment was collected from 10 roots. They were thoroughly washed with distilled water to remove the peat substrate. Root surfaces were sterilised in a solution containing $4 \mathrm{~mL}$ laurylsarcosin $20 \%+32 \mathrm{~mL}$ Ace whitening preparation (about $5 \%$ of sodium hypochlorite) and $64 \mathrm{~mL}$ of sterile water, as recommended by Johnson [23]. The presence or absence of $S$. indica chlamydospores in the 10 fields of view in each of the extracted root fragments was assessed, what means observation on 50 and 100 fragments (500 and 1000 fields of view). Root preparations were stained with cotton blue [27] or analysed without staining under a light microscope Eclipse 80i (Nikon, Tokyo, Japan) at a magnification of $\times 125$.

\subsection{Re-Isolation of P. cinnamomi from Infected Plants and Substrates}

Fragments of diseased stems with a length of about $2-3 \mathrm{~cm}$ were washed under running tap water and then disinfected in a $70 \%$ ethanol solution for 1 minute. The alcohol was removed by washing three times with sterile distilled water, after which the collected fragments were dried with a sterile paper towel and $0.5 \mathrm{~cm}$ sections were laid out on plates with PDA medium and selective media for Phytophthora, PARP (Pimaricin, Ampicillin, Rifampicin, Pentachloronitrobenzene, Sigma-Aldrich, St. Louis, Missouri, USA) [28]. The cultures were incubated at $23^{\circ} \mathrm{C}$ for $2-5$ days and examined daily under a microscope microscope Eclipse 80i (Nikon, Tokyo, Japan). Fragments of growing mycelia indicating affiliation to the Phytophthora genus (hyphae branched almost at right angle, hyphal swellings, after Erwin and Ribeiro, 1996) [24] were laid on PDA medium for identification based on morphology or incubated in liquid organic medium for identification based on molecular markers. The re-isolation 
from the peat substrate was carried out using baiting of pathogen on leaves of the rhododendron cultivar Nova Zembla and blueberry, as in Section 2.3. Additionally, during the experiment, root fragments for isolation of $P$. cinnamomi were taken from plants with disease symptoms that were infected with the pathogen only and where both fungi were inoculated. At the termination of the experiment, root fragments were taken from all plants also without visible disease symptoms.

\subsection{Assessment of Plant Growth and Tracking of Disease}

At the beginning of the experiment, immediately before inoculation with $S$. indica, the number and length of all shoots of all plants was measured. After 24 months (September 2019), at the termination of the experiment, the same measurements were repeated and an increase in length was calculated for each living plant. Data were subjected to statistical analysis using one-way analysis of variance (Statistica v.13.1, Dell Inc., Round Rock, TX, USA), separately for each cultivar, and compared using a Tukey test at $p=0.05$.

\section{Results and Discussion}

\subsection{Colonisation of Roots with S. indica}

S. indica was able to colonise roots of blueberry of the evaluated cultivars (Figure 1). Chlamydospores, as a certificate of root colonisation, were present in each of the analysed plants but not in all root fragments. Percentages of inoculated roots were comparable between both terms of assessment, 9th and 24th month. Usually, fewer root fragments containing $S$. indica chlamydospores were found in plants inoculated with endophyte and pathogen than in those inoculated only with S. indica (Table 1). There were significant differences in colonisation frequency between cultivars. The lowest percentage of colonised roots was found in 'Spartan', which was susceptible to the pathogen and the highest in 'Darrow', which was the most resistant (Table 1). More chlamydospores indicate the possibility of more intensive secondary colonisation of newly formed roots, which enhances the protective potential of the endophyte.

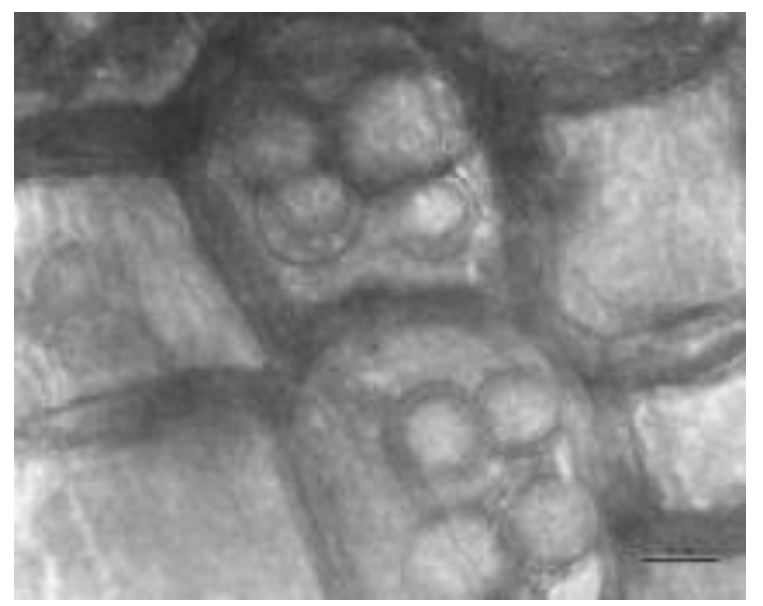

Figure 1. Chlamydospores of S. indica in highbush blueberry root. Bar represents $10 \mu \mathrm{m}$. 
Table 1. Colonisation frequency of roots of highbush blueberry (presence of chlamydospores) with S. indica after 9 and 24 months.

\begin{tabular}{|c|c|c|c|c|}
\hline \multirow[t]{2}{*}{ Cultivar } & $\begin{array}{l}\text { Percentage of } \\
\text { Colonised Roots } \\
\text { of Plants } \\
\text { Inoculated with } \\
\text { S. indica }\end{array}$ & $\begin{array}{c}\text { Percentage of } \\
\text { Colonised Roots } \\
\text { of Plants } \\
\text { Inoculated with } \\
\text { S. indica + } \\
\text { P. cinnamomi }\end{array}$ & $\begin{array}{c}\text { Percentage of } \\
\text { Colonised Roots } \\
\text { of Plants } \\
\text { Inoculated with } \\
\text { S. indica }\end{array}$ & $\begin{array}{c}\text { Percentage of } \\
\text { Colonised Roots } \\
\text { of Plants } \\
\text { Inoculated with } \\
\text { S. indica }+ \\
\text { P. cinnamomi }\end{array}$ \\
\hline & \multicolumn{2}{|c|}{$\begin{array}{l}9 \text { Months ( } 5 \text { Plants } \times 10 \text { Root Fragments } \\
\times 10 \text { Field } s \text { of View }=500 \text { Observations) }\end{array}$} & \multicolumn{2}{|c|}{$\begin{array}{c}24 \text { Months (10 Plants } \times 10 \text { Root } \\
\text { Fragments } \times 10 \text { Fields of View } n=1000 \\
\text { Observations) }\end{array}$} \\
\hline 'Chandler' & $48 b^{*}$ & $42 \mathrm{~b}$ & $51 \mathrm{~b}$ & $43 \mathrm{~b}$ \\
\hline 'Darrow' & $53 c$ & $46 \mathrm{c}$ & $55 \mathrm{c}$ & $48 \mathrm{c}$ \\
\hline 'Spartan' & $37 \mathrm{a}$ & $33 a$ & $40 \mathrm{a}$ & $36 a$ \\
\hline
\end{tabular}

* means in the column followed by the same letter were not significantly different $(p=0.05$; one-way ANOVA, Tukey's multiple range test).

\subsection{Influence of S. indica and P. cinnamomi on Growth of Plants}

A positive effect of $S$. indica on the growth of shoots of the plants not infected with the pathogen was observed in 'Darrow' and 'Spartan' (Table 2). The average increase in the length of all shoots of plants inoculated with S. indica was larger by $11 \%$ in 'Darrow' and $10 \%$ in 'Spartan' plants compared with non-inoculated plants of control. A similar relationship was recorded for the growth of the longest shoots; their increases were larger by $11 \%$ and $12 \%$ compared with the control that was not inoculated with the endophyte. Growth of the main shoots in 'Chandler' were completely independent of endophyte inoculation and even weaker in length of all shoots by $4 \%$ in plants inoculated with $S$. indica. One of the symptoms of blueberry infestation with P. cinnamomi was inhibition of plant growth. Inoculation of $S$. indica before $P$. cinnamomi infection reduced the negative effect of the pathogen on growth of blueberry plants (Table 2). This was particularly visible in 'Spartan'. The average growth increase of all shoots in combination 4 (S. indica + P. cinnamomi infection) was higher by $120 \%$ and in the length of longest shoots by $182 \%$ relative to combination 3 where plants were only infected with P. cinnamomi (Table 2).

Table 2. Influence of inoculation with S. indica and P. cinnamomi, $n=29$, on growth of highbush blueberry and the course of disease as evaluated after 24 months.

\begin{tabular}{|c|c|c|c|c|}
\hline Treatment & $\begin{array}{l}\text { Average Increase in } \\
\text { Length of the } \\
\text { Longest Shoot }(\mathrm{cm})\end{array}$ & $\begin{array}{l}\text { Average Increase in } \\
\text { Length of All Shoots } \\
\text { (cm) }\end{array}$ & $\begin{array}{l}\text { No. of Plants } \\
\text { with Infection } \\
\text { Symptoms }\end{array}$ & $\begin{array}{l}\text { No. of Dead } \\
\text { Plants }\end{array}$ \\
\hline \multicolumn{5}{|c|}{ ‘Chandler' } \\
\hline Control & $20.6 c^{*}$ & $93.1 \mathrm{~d}$ & 0 & 0 \\
\hline S. indica & $20.6 c$ & $89.2 \mathrm{c}(-4 \%)$ & 0 & 0 \\
\hline P. cinnamomi & $8.4 \mathrm{a}$ & 26.9 a $(n=26)$ & $17(59 \%)$ & $3(10 \%)$ \\
\hline S. indica/P. cinn & $16.1 \mathrm{~b}(+92 \%)$ & $46.8 \mathrm{~b}(n=28)(+74 \%)$ & $17(59 \%)$ & $1(3 \%)$ \\
\hline \multicolumn{5}{|c|}{ 'Darrow' } \\
\hline Control & $18.9 \mathrm{~b}$ & $76.6 \mathrm{ab}$ & 0 & 0 \\
\hline S. indica & 20.3 c $(+11 \%)$ & $84.8 \mathrm{~b}(+11 \%)$ & 0 & 0 \\
\hline P. cinnamomi & $10.4 \mathrm{a}$ & $71.0 \mathrm{a}(n=28)$ & $24(83 \%)$ & $1(3 \%)$ \\
\hline S. indica/P. cinn & $18.1 \mathrm{~b}(+74 \%)$ & $73.6 \mathrm{a}(+4 \%)$ & $8(28 \%)$ & 0 \\
\hline \multicolumn{5}{|c|}{ 'Spartan' } \\
\hline Control & $23.0 \mathrm{c}$ & $92.4 \mathrm{c}$ & 0 & 0 \\
\hline S. indica & $27.7 \mathrm{~d}(+12 \%)$ & $95.7 \mathrm{~d}(+10 \%)$ & 0 & 0 \\
\hline P. cinnamomi & $6.8 \mathrm{a}$ & 34.0 a $(n=10)$ & $29(100 \%)$ & $19(66 \%)$ \\
\hline S. indica/P. cinn & $19.2 \mathrm{~b}(+182 \%)$ & $74.7 \mathrm{~b}(n=25)(+120 \%)$ & $26(90 \%)$ & $4(14 \%)$ \\
\hline
\end{tabular}

* means in the column followed by the same letter were not significantly different $(p=0.05$; one-way ANOVA, Tukey's multiple range test). 
S. indica is known for its positive effect on the growth and development of plants, especially young plants, of many species, e.g., during acclimatisation of microplants produced in vitro [16,29]. In our experiments with rhododendron [30], S. indica significantly increased the height of shoots by $36 \%$ in 'Nova Zembla' and 13\% in 'Alfred' after 7 months of the experiment and 33-36\% after 15 months.

\subsection{Influence of S. indica on Protection of Blueberry Plants against P. cinnamomi}

The initial symptoms of infection with Phytophthora were visible as shoot necrosis in July 2018 (Figure 2), followed by diminutiveness, reddening, and dropping of leaves. Twelve months after inoculation with the pathogen, some infected plants were completely dry (dead). In the second year of the experiment, symptoms of phytophthorosis included continuous growth slowdown and formation of smaller diameter shoots (Figure 3). After 24 months, the number of plants visibly infected from which the pathogen was isolated differed between cultivars (Table 2). The percentage of symptomatic plants inoculated only with P. cinnamomi was 59, 83, and 100\% for 'Chandler', 'Darrow', and 'Spartan', respectively. In the treatment where both the endophyte and pathogen were used for inoculation, these percentages were 59, 28, and 90\%, respectively. The highest severity of infection was found in 'Spartan', where $66 \%$ of plants that were not protected and $14 \%$ plants that were protected with S. indica died. In 'Chandler', 3 plants among the non-protected died and only one among the protected (out of 29). In 'Darrow', only one plant among the non-protected died, and none among the protected.

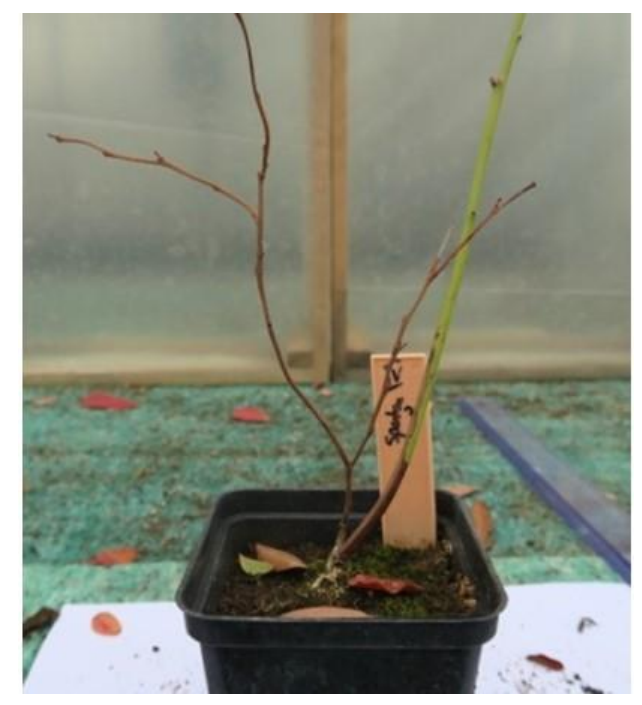

Figure 2. Spread of necrosis on highbush blueberry plant 'Spartan' 10 months after infection with P. cinnamomi.

The severity and course of Phytophthora infection on blueberry was different than that described for rhododendron [21]. Rhododendron plants showed symptoms soon after infection. Within one to two weeks, leaves were bent, wilted, and dried quickly, and all plants died within six weeks in greenhouse experiments [21]. The severity of disease was similarly strong in two cultivars. In contrast, the blueberry plants that were infected at the age of 6 months endured the disease more easily, symptoms were visible later, and only some of them died, although Phytophthora was isolated from the shoots, roots, and substrate. The symptoms of disease on plants that did not die within 2 years of the experiment included stunted growth and development of thinner shoots compared to plants not infected with the pathogen. Root balls were smaller in volume and darker in colour (Figure 4). In contrast to rhododendron [21], the cultivars of highbush blueberry differed in resistance to $P$. cinnamomi. The most susceptible was 'Spartan' and the most resistant was 'Darrow'. To our surprise, the leaves of 'Chandler' and 'Darrow' were resistant to infection with P. cinnamomi spores (they could not capture the pathogen from the substrate) and because of this, it was not possible to use them in baiting for re-isolation of the 
pathogen from the substrate. Only leaves of the most susceptible cultivar, Spartan, were able to be infected with the pathogen (Figure 5). Bryla [9] studied the incidence of Phytophthora and Pythium infections on the blueberry fields of Oregon but did not find symptomatic plants of 'Darrow' among the eleven monitored cultivars.
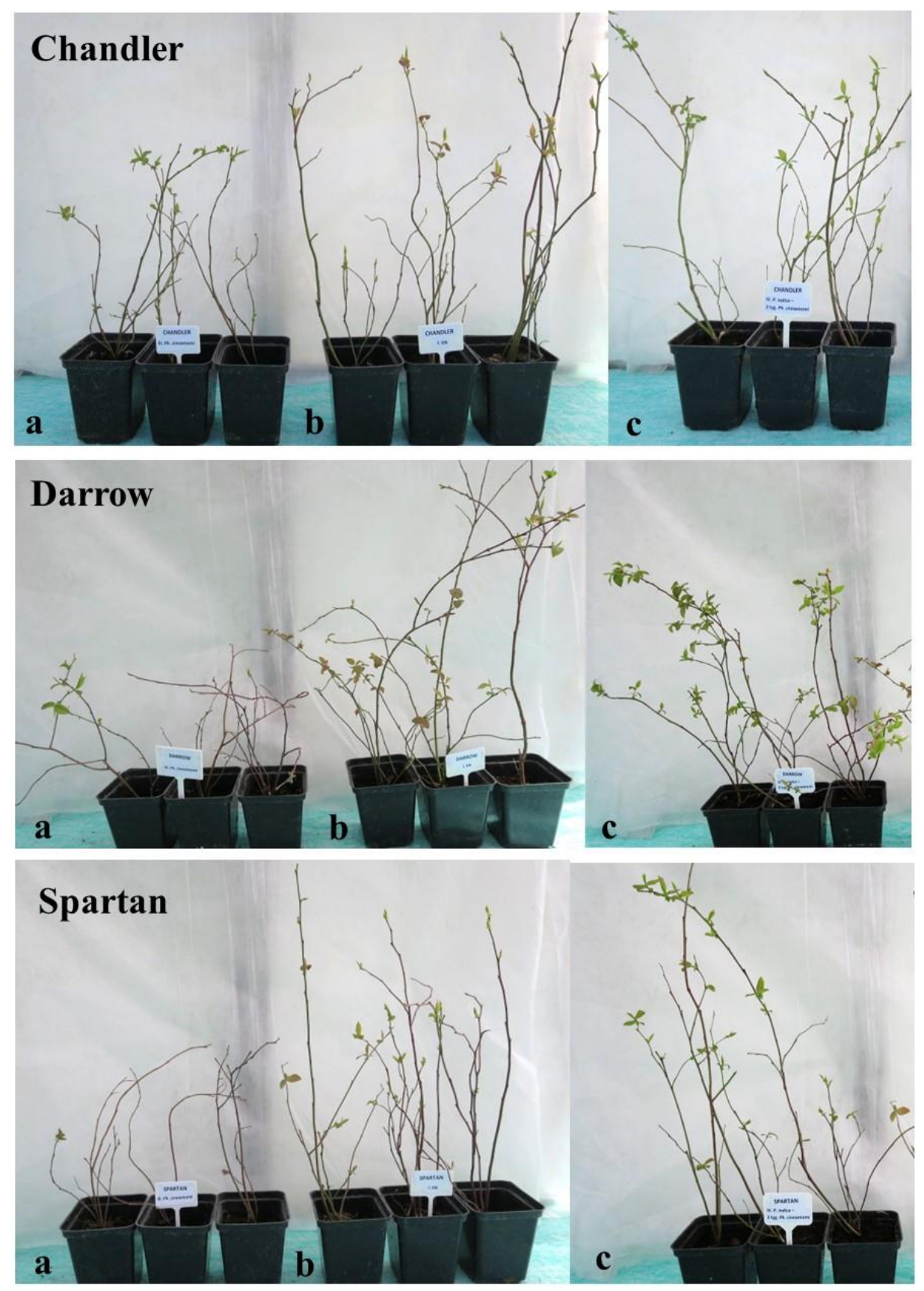

Figure 3. Influence of inoculation of $S$. indica and P. cinnamomi on highbush blueberry plants after 18 months of the experiment. Each of three plants from the left: (a) infected with P. cinnamomi, (b) control (not inoculated), (c) inoculation with $S$. indica, and after 21 days infected with P. cinnamomi. 

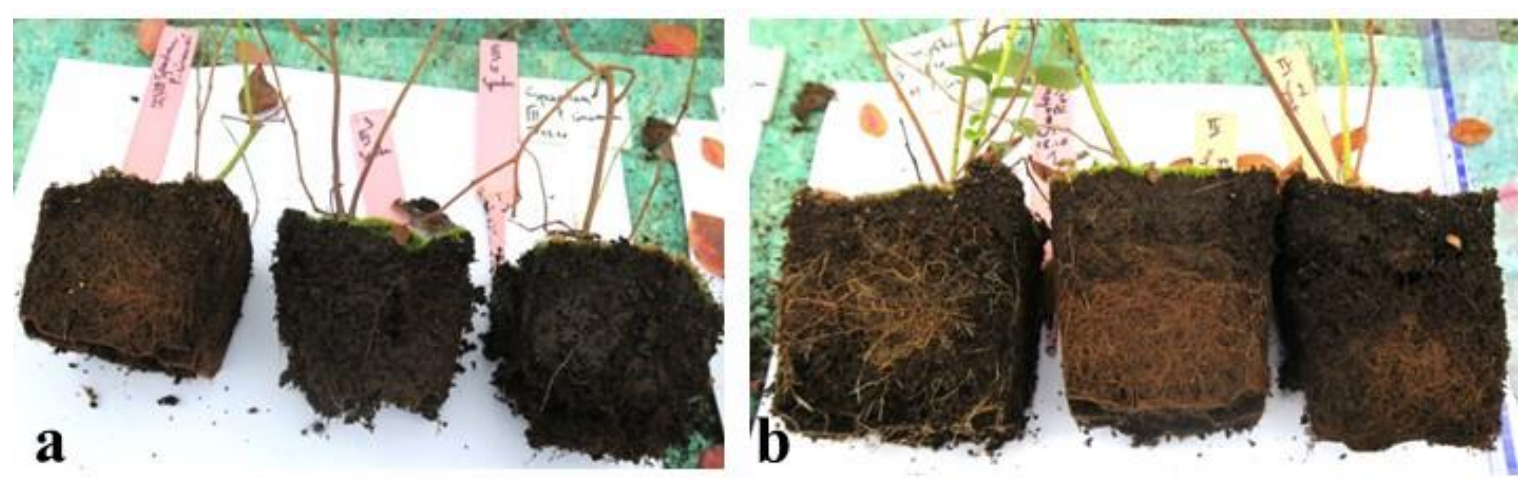

Figure 4. Root balls of highbush blueberry 'Spartan'. (a) Inoculated with P. cinnamomi. (b) Inoculated with Serendipita. indica + P. cinnamomi (after 21 days), after 24 months of the experiment.
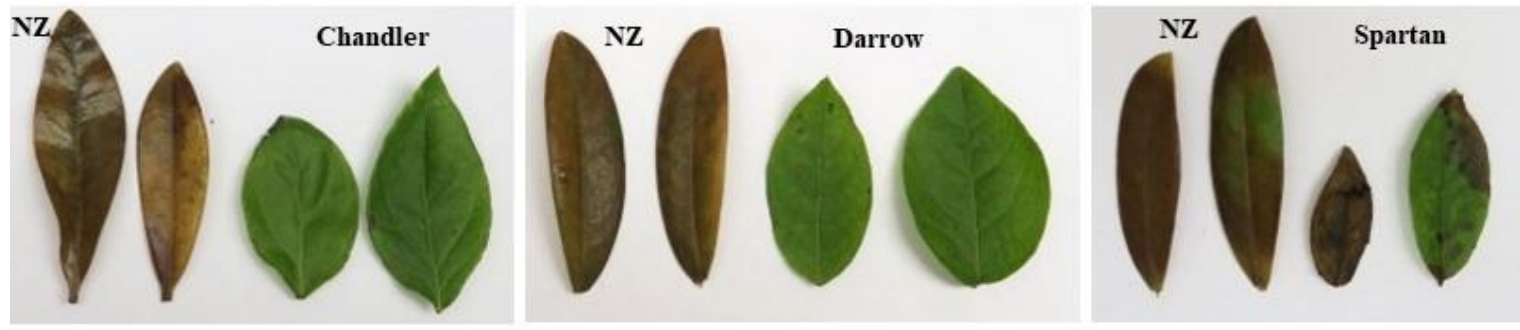

Figure 5. Re-isolation of P. cinnamomi from the substrate on the leaves of rhododendron 'Nova Zembla' (left) and highbush blueberry (right), after 5 days.

Other authors also reported differing susceptibility of blueberry cultivars to Phytophthora [11,31]. In greenhouse conditions, 12- or 18-month-old plants were inoculated and the level of resistance was evaluated on the basis of shoot and root biomass [31] or growth parameters and fresh weight [11] after 16 (the first report) and 13 (the second) weeks. Within this time, no dead plants were observed. In our experiment, some plants died within 2 years. According to Smith [13] and Bryla [9], Phytophthora diseases of blueberry in productional fields can have a chronic character. Diseased plants are characterised by lower productivity but will die under adverse conditions, such as flooding or drought. Symptoms of phytophthorosis on field grown plants look similar to those observed in our greenhouse trial and were characterised with "small, yellow or red leaves, lack of new growth, root necrosis, and a smaller root system, and they gradually died within three years, especially when grown in wet soil" [10]. In older plants, the disease could be chronic and diseased plants were less productive, including the quality and quantity of yield.

\subsection{Re-Isolation of Pathogen from Plants and Substrate}

Our trials on baiting the pathogen from the substrate on leaves resulted in colonisation of rhododendron and blueberry 'Spartan' leaves (Table 3, Figure 5). Baiting was successful from all substrate samples inoculated with P. cinnamomi and in both terms of investigation. The number of necrotic spots showed the amount of pathogen propagules and was the highest in samples where 'Spartan' was grown (Table 4). This can be a starting point to develop a test for the preliminary screening of blueberry genotypes for resistance to this pathogen. 
Table 3. Re-isolation of P. cinnamomi from substrates inoculated with P. cinnamomi on which blueberry plants were grown. Re-isolation was made by baiting on leaves of rhododendron (RH) and highbush blueberry (HB); success (+); lack (-).

\begin{tabular}{|c|c|c|c|c|c|c|c|c|c|c|c|c|}
\hline \multirow{3}{*}{ Cultivar } & \multicolumn{2}{|c|}{ Control } & \multicolumn{2}{|c|}{ P. cinnamomi } & \multicolumn{2}{|c|}{$\begin{array}{l}\text { S. indica }+ \\
\text { P. cinnamomi }\end{array}$} & \multicolumn{2}{|c|}{ Control } & \multicolumn{2}{|c|}{ P. cinnamomi } & \multicolumn{2}{|c|}{$\begin{array}{c}\text { S. indica }+ \\
\text { P. cinnamomi }\end{array}$} \\
\hline & \multicolumn{6}{|c|}{ Term I after 9 Months } & \multicolumn{6}{|c|}{ Term II after 24 Months } \\
\hline & RH & HВ & RH & НВ & RH & НВ & RH & НВ & RH & НВ & RH & НВ \\
\hline 'Chandler' & - & - & + & - & + & - & - & - & + & - & + & - \\
\hline ‘Darrow' & - & - & + & - & + & - & - & - & + & - & + & - \\
\hline 'Spartan’ & - & - & + & + & + & + & - & - & + & + & + & + \\
\hline
\end{tabular}

Table 4. Mean number of necrotic spots per baitrhododendron leaf 'Nova Zembla', $(n=10)$ re-isolated from substrates on which highbush blueberry was grown.

\begin{tabular}{ccc}
\hline Cultivar & P. cinnamomi & S. indica + P. cinnamomi \\
\hline 'Chandler' & $70 \mathrm{a} *$ & $71 \mathrm{a}$ \\
'Darrow' & $69 \mathrm{a}$ & $66 \mathrm{a}$ \\
'Spartan' & $77 \mathrm{~b}$ & $83 \mathrm{~b}$ \\
\hline
\end{tabular}

* means in the column followed by the same letter were not significantly different $(p=0.05$; one-way ANOVA, Tukey's multiple range test).

The idea of bio-protection of this crop was attempted in experiments by De Silva [32] that aimed to promote growth using several beneficial microorganisms. Only the fungus Gliocladium virens Gl. 21 and bacteria Pseudomonas fluorescens PF 5 promoted growth of 'Blueberry'. The experiment demonstrated the usefulness of G. virens to increase blueberry growth in a nursery. Our results are the first on bio-protection of highbush blueberry against pathogens of Phytophthora spp. using the endophytic fungus $S$. indica and may be an introduction to the development of technology for use in blueberry nurseries.

The most important guideline for effective biological protection of blueberries is to know the mechanism of plant's natural defences against Phytophthora root rot, as well as how S. indica enhances the plant's resistance. So far, some elements of the resistance mechanism to Phytophthora spp. have been determined for a few trees and shrubs, but they cannot be considered sufficient for generalisation [33]. Although the $S$. indica endophyte has recently come to be better understood, there is still a lack of complete knowledge about the general mechanism of stimulating resistance in plants [34]. It seems that this fungus very "intelligently" uses the genetic possibilities of the host plant to build a safe niche for itself. In the coming study, we will try to elucidate this issue.

\section{Conclusions}

We can conclude that in the greenhouse pot experiment, S. indica protected highbush blueberry plants against severe phytophthorosis; thus, counteracting growth retardation and reducing the number of symptomatic and dead plants. Highbush blueberry cultivars differ in their sensitivity to P. cinnamomi. The introduction of $S$. indica into the production of highbush blueberry planting material may have the potential to reduce the chemical protection of this plant against P. cinnamomi.

Author Contributions: Conceptualisation, T.O.; Funding acquisition, A.T., A.M.-C.; Investigation, A.T., A.M.-C. and T.O.; Methodology, A.T. and T.O.; Project administration, A.T.; Supervision, T.O.; Writing-Original draft, A.T. and T.O.; Writing-Review \& editing, A.T., T.O. and A.M.-C. All authors have read and agreed to the published version of the manuscript.

Funding: The study was funded by the Polish Ministry of Science and Higher Education through statutory funds (ZBS/4/2019 and ZBS/8/2016) of the Research Institute of Horticulture, Skierniewice, Poland. 
Acknowledgments: The authors would like to thank R. Oelmüler and I. Sheremeti for kindly providing S. indica, Mr. Jan Ciepłucha, owner of the nursery entertainment, for providing highbush blueberry plants, and Lucyna Ogórek for her technical help.

Conflicts of Interest: The authors declare no conflict of interest.

\section{References}

1. Neto, C. Cranberry and blueberry: Evidence for protective effects against cancer and vascular diseases. Mol. Nutr. Food Res. 2007, 51, 652-664. [CrossRef] [PubMed]

2. Michalska, A.; Łysiak, G. Bioactive compounds of blueberries: Post-harvest factors influencing the nutritional value. Int. J. Mol. Sci. 2015, 16, 18642-18663. [CrossRef]

3. Može, S.; Polak, T.; Gašperlin, L.; Koron, D.; Vanzo, A.; Poklar, U.N.; Abram, V. Phenolics in Slovenian bilberries (Vaccinium myrtillus L.) and blueberries (Vaccinium corymbosum L.). J. Agric. Food Chem. 2011, 59, 6998-7004. [CrossRef]

4. $\quad$ Retamales, J.B.; Hancook, J.F. Blueberry, 2nd ed.; CABI: Wallingford, UK, 2018.

5. Brazelton, C.; Young, K. 2016 World Blueberry Statistics and Global Market Analysis. International Blueberry Organization. 2017. Available online: https://www.internationalblueberry.org/2017/05/03/2016-globalblueberry-statistics-and-intelligence-report-is-now-available-at-the-ibos-library/ (accessed on 3 May 2017).

6. Pluta, S.; Żurawicz, E. The High-Bush Blueberry (Vaccinium corymbosum L.) breeding programme in Poland. Acta Hortic. 2014, 1017, 178-180. [CrossRef]

7. Tooley, P.W.; Kyde, K.I.; Englander, L. Susceptibility of selected Ericaceous host species to Phytophthora ramorum. Plant Dis. 2004, 88, 993-999. [CrossRef] [PubMed]

8. Shearer, B.L.; Crane, C.E.; Cochrane, J.A.; Dunne, C.P. Variation in susceptibility of threatened flora to Phytophthora cinnamomi. Austr. Plant Pathol. 2013, 42, 491-502. [CrossRef]

9. Bryla, D.R.; Linderman, R.G. Incidence of Phytophthora and Pythium infection and the relation to cultural conditions in commercial blueberry fields. HortScience 2008, 43, 260-263. [CrossRef]

10. Smith, B.J. Survival of southern highbush blueberry cultivars in Phytophthora root rot-infested fields in South Mississipi. Int. J. Fruit Sci. 2012, 12, 146-155. [CrossRef]

11. Larach, A.; Besoain, X.; Salgado, E. Crown and root rot of highbush blueberry caused by Phytophthora cinnamomi and P. citrophthora and cultivar susceptibility. Cien. Inv. Agr. 2009, 36, 433-442. [CrossRef]

12. Orlikowski, L.B.; Ptaszek, M.; Meszka, B. Phytophthora cinnamomic-New pathogen of high blueberry in Poland. Prog. Plant Prot. 2015, 55, 472-477.

13. Smith, B.J. Cultural practices and chemical treatments affect Phytophthora root rot severity of blueberries grown in south Mississippi. Int. J. Fruit Sci. 2008, 8, 173-181. [CrossRef]

14. Yeo, J.R.; Weiland, J.E.; Sullivan, D.M.; Bryla, D.R. Nonchemical, cultural management strategies to suppress Phytophthora root rot in Northern highbush blueberry. HortScience 2017, 52, 725-731. [CrossRef]

15. Oelmüller, R.; Sherameti, I.; Tripathi, S.; Varma, A. Piriformospora indica, a cultivable root endophyte with multiple biotechnological applications. Symbiosis 2009, 49, 1-17. [CrossRef]

16. Franken, P. The plant strenghthening root endophyte Piriformospora indica: Potential application and the biology behind. Appl. Microbiol. Biotechnol. 2012, 96, 1455-1464. [CrossRef]

17. Varma, A.; Sherameti, I.; Tripathi, S.; Prasad, R.; Das, A.; Sharma, M.; Bakshi, M.; Johnson, J.M.; Bhardwaj, S.; Arora, M.; et al. The symbiotic fungus Pirimospora indica. In Fungal Associations; Hock, B., Ed.; Springer: Berlin/Heidelberg, Germany, 2012; pp. 231-260.

18. Johnson, J.M.; Alex, T.; Oelmueller, R. Piriformospora indica: The versatile and multifunctional root endophytic fungus for enhanced yield and tolerance to biotic and abiotic stress in crop plants. J. Trop. Agric. 2014, 52, 103-122.

19. Rabiey, M.; Ullah, I.; Shaw, L.J.; Shaw, M.W. Potential ecological effects of Piriformospora indica, a possible biocontrol agent, in UK agricultural system. Biol. Control. 2017, 104, 1-9. [CrossRef]

20. Panda, S.; Busatto, N.; Hussain, K.; Kamble, A. Pirimospora indica-primed transcriptional reprogramming induces defense response against early blight in tomato. Sci. Hortic. 2019, 255, 209-219. [CrossRef]

21. Trzewik, A.; Maciorowski, R.; Klocke, E.; Orlikowska, T. The influence of Piriformospora indica on the resistance of two rhododendron cultivars to Phytophthora cinnamomi and P. plurivora. Biol. Control 2020, 140, 104121. [CrossRef] 
22. Hill, T.W.; Keafer, E. Improved protocols for Aspergillus medium: Trace elements and minimum medium salt stock solutions. Fungal Genet. Newsl. 2001, 48, 20-21. [CrossRef]

23. Johnson, J.M.; Sherameti, I.; Ludwig, A.; Nongbri, P.L.; Sun, C.; Lou, B.; Varma, A.; Oelmüller, R. Protocols for Arabidopsis thaliana and Piriformospora indica co-cultivation-A model system to study plant beneficial traits. J. Endocytobiosis Cell Res. 2011, 21, 101-113.

24. Erwin, D.C.; Ribeiro, O.K. Phytophthora Disease Worldwide; APS Press: St. Paul, MN, USA, 1996.

25. White, T.J.; Bruns, T.; Lee, S.; Taylor, J. Amplification and direct sequencing of fungal ribosomal RNA for phytogenetics. In PCR Protocols: A Guide to Methods and Applications; Innis, M.A., Gelfand, D.H., Sninsky, J.J., Whitw, T.J., Eds.; Academic Press: San Diego, CA, USA, 1990; pp. 315-322.

26. Themann, K.; Werres, S.; Diener, H.A.; Luttmann, R. Comparison of different methods to detect Phytophthora spp. in recycling water from nurseries. J. Plant Pathol. 2002, 84, 41-50.

27. Kumar, M.; Yadav, V.; Tuteja, N.; Johri, A.K. Antioxidant enzyme activities in maize plants colonized with Piriformospora indica. Microbiology 2009, 155, 780-790. [CrossRef] [PubMed]

28. Kannwischer, M.E.; Mitchell, D.J. The influence of a fungicide on the epidemiology of black shank of tobacco. Phytopathology 1978, 68, 1760-1765. [CrossRef]

29. Varma, A.; Verma, S.; Sahay, N.; Bütehorn, B.; Franken, P. Piriformospora indica, a cultivable plant-growth-promoting root endophyte. Appl. Environment. Microbiol. 1999, 65, 2741-2744. [CrossRef] [PubMed]

30. Trzewik, A.; Kowalczyk, W.; Maciorowski, R.; Marasek-Ciolakowska, A.; Klocke, E.; Orlikowska, T. Stimulation of ex vitro growth of Rhododendron hybrids 'Nova Zembla' and 'Alfred' by inoculation of roots with Serendipita indica. Hort. Sci. 2020, in press.

31. Yeo, J.R.; Weiland, J.E.; Sullivan, D.M.; Bryla, D.R. Susceptibility of highbush blueberry cultivars to Phytophthora root rot. HortScience 2016, 51, 74-78. [CrossRef]

32. De Silva, A.; Patterson, K.; Rothrock, C.; Moore, J. Growth promotion of highbush blueberry by fungal and bacterial inoculants. HortScience 2000, 35, 1228-1230. [CrossRef]

33. Ruiz-Gómez, F.J.; Pérez-de-Logue, A.; Nawarro-Cerrillo, R.M. The involvement of Phytophthora root rot and drought stress in holm oak decline: From ecophysiology to microbiome influence. Curr. Forestry Reports 2019, 5, 251-266.

34. Saeed-ur-Rahman, M.K.; Huang, D. Molecular mechanism underlying Piriformospora indica-mediated plant improvement/protection for sustainable agriculture. ABBS 2019, 51, 229-242.

Publisher's Note: MDPI stays neutral with regard to jurisdictional claims in published maps and institutional affiliations.

(C) 2020 by the authors. Licensee MDPI, Basel, Switzerland. This article is an open access article distributed under the terms and conditions of the Creative Commons Attribution (CC BY) license (http://creativecommons.org/licenses/by/4.0/). 